\title{
UREGULOWANIA PRAWNE I PRAKTYCZNE ASPEKTY BEZPIECZEŃSTWA I HIGIENY PRACY NA BUDOWIE
}

\author{
Jerzy Obolewicz ${ }^{\bowtie}$
}

Wydział Budownictwa i Inżynierii Środowiska, Politechnika Białostocka, Białystok

\begin{abstract}
STRESZCZENIE
W artykule omówiono uregulowania prawne dotyczące bezpieczeństwa i higieny pracy na terenie budowy w kontekście całego cyklu życia obiektu budowlanego, mające podstawowe znaczenie w utrzymaniu wymaganego poziomu bezpieczeństwa i ochrony zdrowia pracowników budowlanych. Właściwe zastosowanie i interpretacja zagadnień BHP w przygotowaniu, wykonywaniu i eksploatacji obiektu budowlanego ma wpływ na bezpieczny przebieg procesu realizacji obiektu budowlanego. Utrzymanie wymaganego poziomu bezpieczeństwa pracy na budowie wymusza konieczność zrozumienia i zastosowania prawa do identyfikacji i analizy czynników mających wpływ na ten poziom w poszczególnych fazach i czynnościach etapów przygotowania, budowy i eksploatacji obiektu budowalnego.
\end{abstract}

Słowa kluczowe: budownictwo, uregulowania prawne, budowa, bezpieczeństwo i ochrona zdrowia

\section{WSTĘP}

Każde przedsięwzięcie budowlane jest procesem niepowtarzalnych, złożonych i związanych ze sobą działań, przeznaczonych do wykonania w wyznaczonym terminie bez przekraczania ustalonego budżetu i zgodnie z założonymi wymaganiami, w wyniku którego powstają obiekty budowlane: budynki, budowle i obiekty małej architektury (Obolewicz, 2018a, b).

W zarządzaniu przedsięwzięciem budowlanym ważną rolę odgrywa inżynieria, która wraz z rozwojem nauki i techniki nabiera coraz większego znaczenia w praktyce budowlanej. Jej rozważania obejmują problematykę całego procesu inwestycyjnego $\mathrm{w}$ aspekcie technicznym, ekonomicznym i społecznym (Połoński, 2008; Kasprowicz, 2014; Baryłka, 2018; Obolewicz, 2018a).

W inżynierii przedsięwzięć budowlanych analizowane są problemy całego cyklu życia obiektu budowlanego, które obejmują zagadnienia projektowania, budowy i użytkowania (Baryłka, 2018). Ważne miejsce $w$ tych rozważaniach zajmuje problematyka bezpieczeństwa i ochrony zdrowia (BIOZ) pracowników budowlanych (Langford, Rowlings i Sawacha, 2000; Koehn i Datta, 2003; Hinze, Godfrey i Sullivan, 2013; Liu, Jazayeri, Dadi, Maloney i Cravey, 2015).

Doświadczenia praktyczne autora pozwalają na stwierdzenie, że w budowlanym środowisku pracy, niezależnie od miejsca, w którym jest realizowana budowa, zawsze istnieje ryzyko narażenia pracownika budowlanego na czynniki szkodliwe, uciążliwe lub niebezpieczne $\mathrm{w}$ trakcie prowadzonych robót budowlanych (Obolewicz i Dąbrowski, 2017).

Ocena i wybór bezpiecznego rozwiązania powinny być dokonywane ze względu na uregulowania prawne, socjalne i środowiskowe (Obolewicz, 2018a).

Dyrektywy unijne dotyczące bezpieczeństwa pracy i ochrony zdrowia (Dyrektywa Rady UE 92/57/ /EWG) wskazują na potrzebę koordynacji działań w całym budowlanym procesie inwestycyjnym.

凶j.obolewicz@pb.edu.pl 
Podkreśla się w nich zależność bezpieczeństwa i higieny pracy od istniejących systemów zarządzania. W raporcie Europejskiej Agencji Bezpieczeństwa i Zdrowia w Pracy pt. „Osiąganie wyższego poziomu bezpieczeństwa i ochrony zdrowia w budownictwie. Zarządzanie inwestycjami budowlanymi" zwraca się uwagę na konieczność kompleksowego ujęcia zagadnień, tj.: we wszystkich etapach procesu inwestycyjnego: przygotowaniu, realizacji i eksploatacji obiektu budowlanego (EU-OSHA, 2004). Potwierdzają to wyniki badań, w których zauważono i podkreślono zależność między percepcją bezpieczeństwa postrzeganą przez inwestora, projektanta i wykonawce oraz zwrócono uwagę na badania zachowań pracowników budowlanych, ponieważ mają one wpływ na podejmowanie działań przez kierownictwo budowy. Zgodnie w wyżej przedstawionymi wymaganiami zarządzanie bezpieczeństwem i ochrona zdrowia powinno polegać na zapewnieniu warunków i organizacji pracy oraz zachowań pracowników gwarantujących wymagany poziom ochrony zdrowia i życia przed zagrożeniami wystepującymi w budowlanym środowisku pracy. $Z$ analizy statystyki wypadków wynika, że szczególne nasilenie zagrożeń następuje w trakcie budowy i eksploatacji obiektu budowlanego (Hoła, 2004; 2008; 2016; Obolewicz, 2018a). Zagrożenia te mogą powstawać w wyniku niewłaściwego przygotowania inwestycji budowlanej do realizacji, np. $\mathrm{w}$ trakcie projektowania, czy też $\mathrm{w}$ wyniku prowadzenia prac budowlanych niezgodnie z przepisami zasadami bezpiecznej pracy lub niewłaściwą eksploatacją obiektów budowlanych.

Do rozwiązywania problemów bezpieczeństwa i higieny pracy powstających podczas realizacji budowy nie wystarcza podstawowa wiedza, doświadczenie i intuicja pracowników budowlanych. Wymagane jest również zastosowanie podejścia uwzględniającego posiadanie interdyscyplinarnej wiedzy oraz wykorzystującego wyniki badań i opracowania rozwiązań wariantowych w całym procesie realizacji przedsięwzięcia budowlanego, a w szczególności w obszarze projektowania, technologii i organizacji robót (Toole, 2002; ILO, 2004; Runkiewicz, 2006; Pungvongsanuraks i Chinda, 2010; Sabarinah, Zarina, Zaharah i Mustapha, 2013; Seoko i Sangwon, 2013; Obolewicz, 2018a).
Każdy obiekt budowlany należy projektować, budować i eksploatować zgodnie z przepisami techniczno-budowlanymi i zasadami wiedzy technicznej, zapewniając bezpieczeństwo i ochronę zdrowia pracowników budowlanych przez wszystkich uczestników przedsięwzięcia budowlanego (inwestora, inspektora nadzoru inwestorskiego, projektanta, kierownika budowy/kierownika robót, zarządcę obiektu budowlanego). Każdy z nich ponosi odpowiedzialność za BIOZ w określonym zakresie, a w szczególności: inwestor za zorganizowanie procesu budowlanego zgodnie $\mathrm{z}$ wymaganiami BIOZ; projektant za sporządzenie informacji $\mathrm{BIOZ} \mathrm{w}$ procesie budowy; kierownik budowy za sporządzenie lub zapewnienie sporządzenia planu BIOZ oraz koordynowanie działań zapewniających przestrzeganie zasad BIOZ podczas wykonywania robót budowlanych, a w razie powstania zagrożenia za reakcję zgodnie z obowiązującym prawem, a zarządca obiektu budowlanego za jego bezpieczne użytkowanie w myśl Rozporządzenia Ministra Infrastruktury z dnia 12 kwietnia 2002 r. w sprawie warunków technicznych, jakim powinny odpowiadać budynki i ich usytuowanie.

\section{PODSTAWOWE WYMAGANIA DOTYCZACE BEZPIECZEŃSTWA I OCHRONY ZDROWIA NA BUDOWIE}

Pojęcie bezpieczeństwa jest trudne do jednoznacznego zdefiniowania. Kształtująca się współcześnie nauka o bezpieczeństwiejest interdyscyplinarna-wykorzystuje dorobek innych dyscyplin naukowych. Interdyscyplinarność powoduje, że pojęcie to może być definiowane z punktu widzenia wielu dyscyplin, a w związku z tym również $\mathrm{z}$ punktu widzenia budownictwa. Zdaniem Ejdys, Lulewicz i Obolewicza (2008) nurt związany z organizowaniem bezpiecznych warunków pracy pojawił się w Polsce pod koniec lat 80 . XX wieku. Działaniom tym nadano nazwę zarządzania bezpieczeństwem. W literaturze angielskojęzycznej i polskiej rozróżnia się pojęcia bezpieczeństwa i higieny pracy (BHP). Bezpieczeństwo związane jest wówczas z ochroną życia, a higiena $z$ ochroną zdrowia (Obolewicz, 2013, 2018a). Najogólniej można powiedzieć, że bezpieczeństwo na budowie to stan niezagrożenia, spokoju i pewności jej uczestników (Szymczak, 1994). 
Wraz z rozwojem nauki i techniki podejście do problematyki BHP $\mathrm{w}$ budownictwie ulegało ciągłym przemianom. Zaangażowanie na rzecz BHP było zróżnicowane w zależności od wielkości przedsiębiorstwa i jego kondycji finansowej. Początkowo bardziej efektywne były duże przedsiębiorstwa państwowe, w których funkcjonowały służby odpowiedzialne za warunki pracy, gorzej natomiast było w małych i średnich przedsiębiorstwach prywatnych, w których sprawy BHP były traktowane marginalnie. Wraz ze zmianami na rynku budowlanym i z wejściem kapitału zagranicznego sytuacja BHP $\mathrm{w}$ polskim budownictwie polepszyła się głównie za sprawą korporacji międzynarodowych, takich jak np.: Skanska AB (Szwecja), Stragag (Austria) czy Hochtief (Niemcy), w których już funkcjonowały systemy BHP, oraz dzięki inicjatywie polskich przedsiębiorców, która było porozumienie zawarte w 2010 roku w celu wyeliminowania wypadków z placów budów. Obecnie porozumienie to tworzą: Budimex, Erbud, Hochtief, Karmar, Mostostal Warszawa, Mota-Engil, Polimex-Mostostal, Porr, Skanska, Strabag, Unibep i Warbud.

Z punktu widzenia organizacji każda budowa jest formą organizacyjną majacca określony stan wyjściowy BIOZ zmieniający się wraz z postępem robót budowlanych. $\mathrm{Z}$ zasady jest on oparty na wymogach określonych prawem lub/i zawiera elementy, które dodatkowo przyczyniają się do podniesienia poziomu bezpieczeństwa pracy, np. poprzez porozumienia, regulaminy czy instrukcje.

Zgodnie z obowiązującym Kodeksem pracy pracodawca jest obowiązany chronić zdrowie i życie pracowników poprzez zapewnienie bezpiecznych i higienicznych warunków pracy. Osobą odpowiedzialną za organizację i przebieg budowy jest kierownik budowy. W zależności od wielkości i złożoności budowy kierownik budowy sam organizuje i nadzoruje roboty wykonywane przez pracowników lub współpracuje w tym zakresie z kierownikami robót, a także podejmuje działania w celu zapewnienia BIOZ.

W przepisach dotyczących BHP podczas wykonywania robót na budowie nałożono dodatkowe obowiązki na kierownika budowy. Obejmują one przede wszystkim: opracowanie planu BIOZ, przeprowadzenie szkolenia pracowników (uczniów), zapewnienie ochrony przeciwpożarowej oraz zapewnienie bez- piecznej eksploatacji maszyn i urządzeń technicznych oraz koordynację robót $\mathrm{w}$ trakcie prowadzenia budowy pod względem BHP.

\section{Plan BIOZ}

Kierownik budowy ma obowiązek spowodowania lub sporządzenia przed rozpoczęciem robót na budowie planu BIOZ wtedy, gdy przewidywany czas budowy przekracza 30 dni roboczych i jednocześnie jest zatrudnionych do niej więcej niż 20 pracowników lub pracochłonność przekracza 500 osobodni oraz gdy prowadzone roboty na budowie stwarzają szczególnie duże ryzyko zagrożenia bezpieczeństwa i zdrowia ludzi, pracownicy narażeni są na działanie substancji chemicznych lub czynników biologicznych, prace są wykonywane w pobliżu linii wysokiego napięcia lub czynnych linii komunikacyjnych oraz gdy prace są prowadzone pod ziemią, stwarzają ryzyko utonięcia, są wykonywane w kesonach, wymagają użycia materiałów wybuchowych lub są związane z montażem i demontażem ciężkich elementów prefabrykowanych.

Plan BIOZ składa się ze strony tytułowej, z części opisowej i części rysunkowej. Szczegółowy zakres tych części określony został w Rozporządzeniu Ministra Infrastruktury z dnia 23 czerwca 2003 r. w sprawie informacji dotyczącej bezpieczeństwa i ochrony zdrowia oraz planu bezpieczeństwa i ochrony zdrowia.

W części opisowej planu BIOZ powinien się znaleźć m.in.: opis procesu, w trakcie którego powstaje obiekt budowlany; informacje dotyczące przewidywanych zagrożeń $\mathrm{w}$ poszczególnych robotach budowlanych występujących $\mathrm{w}$ procesie; informacje o sposobie prowadzenia instruktażu pracowników; o zasadach postępowania $\mathrm{w}$ wypadku zagrożenia i konieczności stosowania środków ochronnych oraz informacje o miejscu przechowywania dokumentacji budowy.

Część rysunkową planu BIOZ należy sporządzić na kopii planu zagospodarowania terenu budowy i w szczególności: oznaczyć czynniki mogące stwarzać zagrożenie; rozmieścić i oznaczyć strefy zagrożenia oraz rozmieszczenia urządzeń przeciwpożarowych i sprzętu ratunkowego; przedstawić rozwiązania komunikacyjne wraz z ogrodzeniem terenu budowy; zlokalizować pomieszczenia higieniczno-sanitarne. 


\section{Szkolenie pracowników (uczniów)}

Według Kodeksu pracy nie można dopuścić pracownika do pracy, jeżeli nie posiada on wymaganych kwalifikacji, nie umie jej wykonywać lub nie zna przepisów i zasad BHP. Dotyczy to zarówno pracowników zatrudnionych na stanowiskach robotniczych i kierowniczych. Szkolenie pracowników w dziedzinie BHP powinno odbywać się w godzinach pracy, na koszt pracodawcy i obowiązkowo przed rozpoczęciem pracy. Może być prowadzone jako: szkolenie wstępne w formie szkolenia ogólnego (instruktaż ogólny), w tym na stanowisku pracy (instruktaż stanowiskowy), i podstawowego; szkolenie i doskonalenie okresowe, które jest obowiązkowe dla pracowników pełniących funkcje kierownicze.

Instruktaż ogólny obejmuje wszystkich nowozatrudnionych pracowników oraz uczniów przed dopuszczeniem do pracy. $\mathrm{W}$ trakcie tego szkolenia należy zapoznać uczestników z podstawowymi zasadami BHP zawartymi w Kodeksie pracy, regulaminie pracy obowiązującym na budowie oraz zasadami udzielania pierwszej pomocy. Instruktaż prowadzi wyznaczony przez pracodawcę pracownik mający odpowiednie przygotowanie z zakresu BHP.

Instruktaż stanowiskowy jest przeprowadzony przed dopuszczeniem do pracy na określonym stanowisku. Jeżeli pracownik zmienia stanowisko pracy lub zmieniają się istotne warunki pracy, np. technologia lub organizacja robót, należy również przeprowadzić szkolenie na stanowisku pracy. Może to zrobić kierownik budowy, kierownik robót lub majster.

Instruktaż ogólny i stanowiskowy powinien być potwierdzony przez pracownik na piśmie oraz odnotowany w aktach osobowych pracownika.

Szkolenie wstępne podstawowe powinno zapewnić pracownikowi nabycie wiedzy i umiejętności niezbędnych do wykonywania lub organizowania pracy zgodnie z zasadami BHP. Dotyczy ono wszystkich nowozatrudnionych na stanowiskach kierowniczych (kierownika budowy, kierowników robót, majstrów, brygadzistów) oraz robotników budowlanych. Szkolenie to należy przeprowadzić w sześć miesięcy od rozpoczęcia pracy na danym stanowisku.
Szkolenie i doskonalenie okresowe obejmuje karę kierowniczą budowy i polega na aktualizacji oraz ugruntowaniu wiadomości i umiejętności z dziedziny BHP nabytych w czasie wcześniejszych szkoleń. Szkolenia te należy organizować nie rzadziej niż co sześć lat.

\section{Ochrona przeciwporażeniowa}

Każdy plac budowy jest wyposażony w sieć oraz urządzenia elektryczne i w związku z tym występuje duże zagrożenie porażeniem prądem elektrycznym. Nakłada to obowiązek na kierownictwo budowy zapobiegania przypadkowemu działaniu prąu na organizm człowieka. Rygorystyczne przestrzeganie zasad, które zapewniają pracownikom bezpieczeństwo i ochronę przed porażeniem prądem, jest więc konieczne. Ważne jest, aby wszystkie roboty związane $\mathrm{z}$ podłączeniem, konserwacją oraz naprawą instalacji i urządzeń elektrycznych na budowie wykonywał elektryk posiadający odpowiednie uprawnienia, wyposażony w środki ochrony indywidualnej, a w ochronie przeciwporażeniowej stosowane były tablice ostrzegawcze, informacyjne lub zakazu.

\section{Eksploatacja maszyn i urządzeń technicznych}

Maszyny, urządzenia techniczne, narzędzia zmechanizowane stosowane na budowie powinny być montowane, eksploatowane i obsługiwane zgodnie $\mathrm{z}$ instrukcją producenta, a obiekty techniczne, które podlegają dozorowi technicznemu, powinny mieć aktualne dokumenty dopuszczające do użytkowania. Szczególną uwagę należy zwrócić na zagrożenia, jakie mogą podczas prac wykonywanych z użyciem: żurawi, wyciągów i dźwigów budowlanych przyściennych i wolnostojących, rusztowań i pomostów oraz narzędzi specjalistycznych.

\section{PLANOWANIE BEZPIECZNEGO PROCESU BUDOWLANEGO}

Według obowiązującego Prawa budowlanego kierownik budowy jest odpowiedzialny za bezpieczny przebieg robót na budowie. W praktyce oznacza to, że planuje, organizuje i koordynuje poszczególne roboty występujące $\mathrm{w}$ procesie budowlanym. 


\section{Planowanie bezpieczeństwa i ochrony zdrowia budowy}

Planowanie bezpiecznego przebiegu procesu budowy polega na wykonaniu następujących czynności:

- identyfikacji robót w procesie budowlanym i wyliczeniu liczby robót do wykonania;

- opracowaniu projektu technologii wykonania poszczególnych etapów budowy (czynności procesu budowlanego) poprzez: podjęcie decyzji o sposobie wykonywania robót budowlanych (ręcznie czy mechanicznie); dobór rodzaju maszyn i urządzeń niezbędnych do robót występujących w procesie; opracowanie schematów pracy i wyliczenie wydajności maszyn i urządzeń technicznych;

- opracowaniu projektu organizacji robót budowlanych występujących w procesie poprzez: wyliczenie liczby brygad roboczych i czasu trwania poszczególnych robót budowlanych; analizę przebiegu robót w czasie całego procesu budowlanego, np. poprzez zastosowanie sieci zależności, dzięki której można tak zorganizować roboty budowlane, aby nie przekroczyć terminu oddania obiektu do użytkowania; zaplanowanie i przedstawienie $\mathrm{w}$ formie harmonogramu przebiegu robót procesowych w czasie trwania budowy; wykonanie zagospodarowania budowy $\mathrm{w}$ formie graficznej $\mathrm{z}$ dokładnym rozmieszczeniem zasobów w terenie;

- sporządzeniu planu bezpieczeństwa i ochrony zdrowia dla analizowanej budowy na podstawie projektu technologii i organizacji robót poprzez: identyfikację i charakterystykę zagrożeń z uwzględnienie ich skali oraz miejsca i czasu występowania; przedstawienie zagrożeń na projekcie zagospodarowania terenu budowy;

- analizie ekonomicznej czynności występujących w procesie robót budowlanych.

Przykładowy schemat procedury do sporządzania planu BIOZ przedstawiono na rysunku.

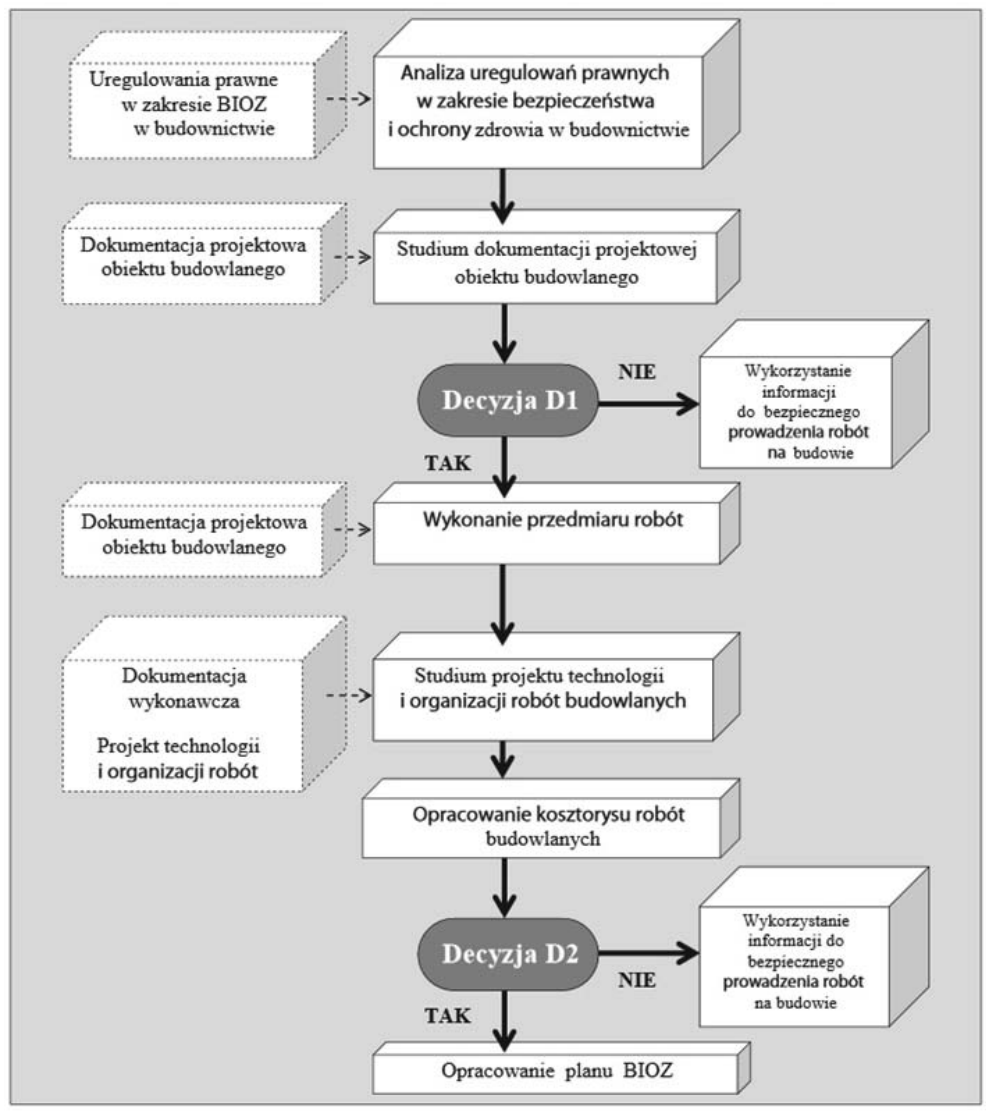

Rys. Przykładowy schemat procedury opracowywania planu bezpieczeństwa i ochrony zdrowia (Obolewicz, 2012)

Fig. An exemplary scheme of the procedure for developing a safety and health plan (Obolewicz, 2012) 


\section{Organizowanie bezpieczeństwa i ochrony zdrowia na budowie}

Organizowanie bezpiecznego przebiegu robót na budowie polega na sprowadzeniu w odpowiednim czasie i bezpiecznym zagospodarowaniu zasobów (pracowników, materiałów i obiektów technicznych) niezbędnych do przeprowadzenia robót procesowych na budowie.

\section{Koordynowanie działań na budowie w celu utrzymania właściwego poziomu bezpieczeństwa i ochrony zdrowia}

Koordynowanie działań w trakcie budowy polega na organizowaniu działań wykonywanych wspólnie dla wszystkich pracowników zgodnie z przepisami i zasadami bezpieczeństwa i ochrony zdrowia. Pomocnym w tych działaniach jest wcześniej opracowany plan BIOZ. Jeżeli w trakcie prowadzenia robót pojawią się nieścisłości lub zagadnienia nieujęte w planie BIOZ, należy wprowadzić korektę do planu i uwzględnić w programie warunki rzeczywiste, które pojawiły się $\mathrm{w}$ trakcie prowadzenia robót.

\section{UTRZYMANIE WYMAGANEGO POZIOMU BEZPIECZEŃSTWA I OCHRONY ZDROWIA NA BUDOWIE}

Proces powstawania obiektu budowlanego jest rozłożony w czasie. W początkowej fazie planowany do wykonania obiekt jest wirtualny - widoczny na projekcie, który wraz z postępem robót budowlanych na budowie systematycznie przekształca się w rzeczywisty - obiekt budowlany. $\mathrm{W}$ trakcie budowy zmieniają się ilości zasobów budowlanych i wraz z nimi parametry BIOZ ulegają zmianie. Przed rozpoczęciem budowy zakłada się, że proces rozpoczęto w sposób zgodny $\mathrm{z}$ obowiązującymi normami i wymaganiami BHP. Od momentu rozpoczęcia budowy wymagania stawiane $\mathrm{w}$ zakresie BHP wzrastają. Sa one następstwem postępu prac budowlanych, postępu technicznego, gospodarczego i społecznego. Są to zjawiska występujące globalnie, spowodowane m.in. zmianą przepisów, uregulowań wewnętrznych i zasad lub rozpoczęciem kolejnego etapu procesu, podczas którego obowiązują nowe wymagania. Wraz z postępem robót zmienia się liczba działań procesowych. Zmienia się także percepcja i zachowania pracowników. Praktycznie poziom BIOZ się obniża. Może to być spowodowane przyczynami ludzkimi, organizacyjnymi i technicznymi, np. większą liczbą uczestników biorących udział w procesie realizacji przedsięwzięcia budowlanego (Obolewicz, 2012).

Zadaniem kierownictwa budowy jest koordynacja działań w celu utrzymania właściwego poziomu BHP na budowie. Na budowie, na której nie będą prowadzone działania w tym zakresie, poziom BIOZ może szybko obniżyć się i osiągnąć stan stwarzający zagrożenie wypadkiem lub chorobą zawodową. Może on być spowodowany większą liczbą wbudowanych elementów budowlanych, rozpoczęciem kolejnych robót budowlanych lub następstwem nieprawidłowego zachowania człowieka na etapie przygotowania czy prowadzenia robót budowlanych. Kiedy poziom BIOZ obniży się, kierownictwo budowy/robót powinno podjąc działania, w wyniku których „obniżanie się” poziomu BIOZ zostanie zatrzymane np. poprzez wprowadzenie nowych uregulowań dotyczących BIOZ czy przeprowadzenie szkolenia.

\section{PODSUMOWANIE}

Problematyka bezpieczeństwa i ochrony zdrowia pracowników na budowie jest niewłaściwie interpretowana przez wielu uczestników procesu inwestycyjnego. Często jest utożsamiana, a także zawężana do przepisów oraz zasad bezpieczeństwa i higieny pracy obowiązujących na budowie. Taka interpretacja ogranicza problematykę BIOZ do zagadnień BHP. Należy pamiętać, że o bezpieczeństwie i ochronie zdrowia pracowników na budowie decydują wszyscy uczestnicy procesu inwestycyjnego, tj.: inwestor, inspektor nadzoru inwestorskiego, projektant, kierownik budowy/ /kierownik robót, pracodawca, pracownik oraz instytucje ich wspomagające i kontrolujące. Ich zadaniem jest dopilnowanie, aby wszystkie prace realizowane w trakcie życia obiektu budowlanego były właściwie oraz bezpiecznie zaplanowane i zorganizowane.

\section{PIŚMIENNICTWO}

Baryłka, A. (2018). Poradnik rzeczoznawcy budowlanego. Tom I. Problemy techniczno-prawne diagnostyki obiektów budowlanych. Łomianki: Oficyna Wydawnicza Centrum Rzeczoznawstwa Budowlanego. 
Dyrektywa Rady (92/57/EWG) z dnia 24 czerwca 1992 r. w sprawie wdrożenia minimalnych wymagań bezpieczeństwa i ochrony zdrowia na tymczasowych lub ruchomych budowach (ósma szczegółowa dyrektywa w rozumieniu art. 16 ust. 1 dyrektywy 89/391/EWG). Dz.U. L 245 z 26.8.1992.

Ejdys, J., Lulewicz, A. i Obolewicz, J. (2008). Zarzqdzanie bezpieczeństwem $w$ przedsiębiorstwie. Białystok: Wydawnictwo Politechniki Białostockiej.

European Agency for Safety and Health at Work [EU-OSHA] (2004). Achieving better safety and health in construction. Information report. Retrived from https://osha.europa.eu/sites/default/files/publications/documents/en/publications/reports/314/TE5904136ENC_-_Achieving_better_safety_and_health_in_construction.pdf

Hinze, J., Godfrey, R. i Sullivan, J. (2013). Integration of Construction Worker Safety and Health in Assessment of Sustainable Construction. Journal of Construction Engineering and Management ASCE, 139 (6), 594-600.

Hoła, B. (2004). Analysis of accident situation in Polish construction industry in period proceeding accession to the European Union. Journal of Civil Engineering and Management, 10, Supplement 2, 107-113.

Hoła, B. (2008). Modelowanie jakościowe i ilościowe wypadkowości w budownictwie. Prace Naukowe Instytutu Budownictwa Politechniki Wrocławskiej. Monografie, 89 (38), 161.

Hoła, B. (2016). Bezpieczeństwo pracy w procesach budowlanych. Wrocław: Oficyna Wydawnicza Politechniki Wrocławskiej.

International Labour Organizational [ILO] (2004). Global Strategy on Occupational Safety and Health. Geneva.

Kasprowicz, T. (2015). Inżynieria przedsięwzięć budowlanych. W T. Kasprowicz (red.), Inżynieria przedsięwzięć budowlanych. Rekomendowane metody i techniki (strony 10-20). Warszawa: Polska Akademia Nauk Komitet Inżynierii Lądowej i Wodnej.

Koehn, E. i Datta, N.K. (2003). Quality, Environmental and Health and Safety Management Systems for Construction Engineering. Journal of Construction Engineering and Management ASCE, 129 (5), 562-569.

Langford, D., Rowlings, S. i Sawacha, E. (2000). Safety behavior and safety management: its influence on the attitudes of workers in the UK construction industry. Engineering, Construction and Architectural Management, 7 (2), 133-140.

Liu, H., Jazayeri, E., Dadi, G. B., Maloney, W. F., i Cravey, K. J. (2015). Development of an operational excellence model to improve safety for construction organizations. W Proceedings of the 5th International Construction
Specialty Conference 2015. Canadian Society of Civil Engineering, Vancouver, CA. Retrieved from http://creativecommons.org/licenses/by-nc-nd/2.5/ca/

Obolewicz, J. (2012). Modelowanie BIOZ w budownictwie. Archiwum Instytutu Inżynierii Ladowej, 13 (201), 247-253.

Obolewicz, J. (2013). Assessment of legal and administrative health and safety in the construction sector after Poland accession to the European Union. Actual Problems of Economics, 12, 447-456.

Obolewicz, J. (2018a). Demoskopia bezpieczeństwa i ochrony zdrowia przedsięwzięć budowlanych. Białystok: Oficyna Wydawnicza Politechniki Białostockiej.

Obolewicz, J. (2018b). Zagospodarowanie placu budowy - wymagania i standardy. Informator Budowlany, 1, 200-204.

Obolewicz, J. i Dąbrowski, A. (2018). An application of the Pareto Method in Surveys to Diagnose the Managers and Workers Perception of Occupational Safety and Health on Selected Polish Construction Sites. International Journal of Occupational Safety and Ergonomics (JOSE), 24 (3), 406-421. DOI: 10.1080/10803548.201 7.1375781

Połoński, M. (2008). Wiadomości ogólne o procesie inwestycyjnym w budownictwie. W M. Połoński (red.), Proces inwestycyjny $i$ eksploatacja obiektów budowlanych (strony 9-29). Warszawa: Wydawnictwo SGGW.

Pungvongsanuraks, P., i Chinda, T. (2010). Investigation of safety perceptions of management and workers in Thai construction industry. Suranaree Journal of Science and Technology, 17 (2), 177-191.

Rozporządzenie Ministra Infrastruktury z dnia 12 kwietnia 2002 r. w sprawie warunków technicznych, jakim powinny odpowiadać budynki i ich usytuowanie. Dz.U. $2002 \mathrm{nr} 75$, poz. 690.

Rozporządzenie Ministra Infrastruktury z dnia 23 czerwca 2003 r. w sprawie informacji dotyczącej bezpieczeństwa i ochrony zdrowia oraz planu bezpieczeństwa i ochrony zdrowia. Dz.U. 2003 nr 120, poz. 1126.

Runkiewicz, L. (2006). O awariach i katastrofach budowlanych w Polsce w latach 1962-2004. Inżynieria i Budownictwo, 4, 193-195.

Sabarinah, S. A., Zarina, I., Zaharah, Y. i Mustapha, M. S. (2013). Knowledge Sharing of Research Information for Construction Health and Safety Practices. Procedia - Social and Behavioral Sciences, 105, 239-248.

Seoko, Ch. i Sangwon H. (2013). Analyses of systems theory for construction accident prevention with specific reference to OSHA accident reports. International Journal of Project Management, 31, 1027-1041. 
Szymczak M. (red). Słownik języka polskiego. Warszawa: PWN.

Toole, T. M. (2002). Construction site safety roles. Journal of Construction Engineering and Management, 128 (3), 203-210.
Ustawa z dnia 26 czerwca 1974 r. Kodeks pracy. Dz.U. 1974 nr 24, poz. 141 z późn. zm.

Ustawa z dnia 7 lipca 1994 r. Prawo budowlane. Dz.U. 1994 nr 89 poz. 414 z późn. zm.

\title{
LEGAL REGULATIONS AND PRACTICAL ASPECTS OF OCCUPATIONAL HEALTH AND SAFETY AT THE CONSTRUCTION SITE
}

\begin{abstract}
The article discusses legal regulations concerning occupational health and safety at the construction site in the context of the whole life cycle of a building, which are of fundamental importance in maintaining the required level of safety and health protection for construction workers. The correct application and interpretation of health and safety issues in the preparation, construction and operation of a building has an impact on the safe course of the construction process. Maintaining the required level of work safety at the construction site forces the necessity to understand and apply the law to identify and analyze factors affecting this level in individual phases and activities of the stages of preparation, construction and operation of the construction site.
\end{abstract}

Key words: construction, legal regulations, construction, safety and health protection 